\title{
Eco-cities: a global survey 2009
}

\author{
S. Joss \\ University of Westminster, UK
}

\begin{abstract}
In the last couple of decades, efforts to render cities environmentally and socially sustainable have culminated in a new phenomenon - the so-called eco-city. Throughout the 1980s and early 1990s, the term 'eco-city' remained mainly a concept, a collection of ideas and propositions about sustainable urban planning, transportation, housing, public participation and social justice, with practical examples relatively few and far between. Since the mid 2000s, the phenomenon appears to have become increasingly global and mainstream, against the background of the international recognition of the scale and severity of climate change and rapid urbanisation, particularly in the developing world. To date, there have been few systematic surveys of eco-cities. This paper presents the findings of a global survey carried out in 2009. The study maps, analyses and compares some 79 identified eco-city initiatives, and addresses questions, such as what are key features that distinguish eco-cities from 'normal' cities; how to define them; why they have become international and mainstream in a short period of time; and what kind of issues their implementation in different contexts raise. The paper concludes by outlining a prospective research agenda aimed at critically discussing eco-cities' capacity for innovating for environmental and social sustainability and related governance processes and challenges.

Keywords: eco-city, eco-town, global survey, typology, new development, urban expansion, retro-fit, innovation, governance.
\end{abstract}

\section{Introduction}

In spring 2009, President Sarkozy of France announced that Paris would become the 'first post-Kyoto eco-city' as part of his ambitious plan to transform the French capital into an expanded, regenerated greater metropolis (Chrisafis, [1]). Later that year, the British government published its decision to build four new 'eco-towns' across England, following a two-year and at times heated public 
consultation process (Department of Communities and Local Government, [2]). In the meantime, on the outskirts of Abu Dhabi the construction of Masdar City [3], the self-proclaimed 'world's first carbon-neutral zero-waste' city is underway, while China is reported to have embarked on an ambitious programme to build some 40 new eco-cities (Wong, [4]).

Thus, in the space of only a few years, in the second half of the 2000s, ecocities appear to have become something of a global, mainstream phenomenon, with countries and cities competing to take a lead in developing and applying new socio-technological innovations and thus bringing about the next generation of sustainable towns and cities. However, it is not immediately clear exactly how significant a phenomenon eco-cities have become, in terms of both global spread and policy significance. Furthermore, it remains to be seen what are key defining characteristics of eco-cities, and indeed what distinguishes eco-cities from 'normal' cities. Finally, light needs to be shed on what gives impulse to the development of eco-city initiatives.

In response, this paper, firstly, aims to map the recent eco-city phenomenon by identifying recent eco-city initiatives, as to date few systematic global surveys have been carried out (for an early survey, with focus on smaller 'econeighbourhoods', see Barton [5]; for a recent in-depth discussion of several ecocity initiatives, see Downton [6]). Secondly, the paper seeks to identify and define key eco-city features, in order both to discern differences and similarities within the 'eco-city' category and to demarcate the boundaries between ecocities and 'normal' cities. Based on this analysis, thirdly, the paper discusses the eco-city phenomenon as a response to the twin issues of global climate change and urbanisation. The paper concludes by sketching out a future research agenda, with special focus on innovation and governance issues.

\section{Historical and conceptual perspectives}

Before considering the findings of this survey, it is worth briefly tracing the roots of the eco-city phenomenon. As has been well documented, efforts to render cities environmentally and socially sustainable are not new. Urban planning and regeneration over the last one hundred years or so have been significantly influenced by attempts to redress the perceived detrimental effects of large-scale urbanisation, such as environmental degradation, social inequalities and urban sprawl. The Garden City, New Town and Techno-City are nineteenth and twentieth century exemplars of such attempts to reinvent the city in the (post)industrial era (e.g. Kargon and Molella [7]). While these earlier concepts and models have undoubtedly had a bearing on the current eco-city development, the latter has its own distinctive characteristics and history, reflecting the rise in environmental and urban policy and politics over the last 40 years or so and in particular global sustainability and climate change politics since the 1990s.

The term 'eco-city' itself can be traced back to the 1980s, when it was first coined in the context of the rising environmental movement, notably by Richard Register through his Urban Ecology initiative and the publication of Eco-City Berkeley [8]. This led to the first international eco-city conference held in 
Berkeley in 1990. Throughout the 1980s and early 1990s, it remained mainly a (normatively prescriptive) concept, "a collection of...ideas about urban planning, transportation...housing, economic development...public participation and social justice..." according to Roseland [9], with practical examples relatively few and far between. As Barton [5] noted, there was initially a considerable gulf between aspiration and actual achievement resulting from various economic, political and behavioural constraints inhibiting the realisation of eco-city developments.

The United Nations 'Earth Summit' (Rio de Janeiro, 1992) and the resulting sustainable development programme ('Agenda 21') formed the background, against which eco-city concepts were increasingly translated into practice. As part of this second phase of development, for example, Curitiba (Brazil) was heralded as an early model eco-city, on account of its advanced, integrated public transport system first initiated in the early 1980s (Macedo, [10]). Waitakere (New Zealand) became known for its attempt to integrate Western and Maori concepts of sustainable resource management in its eco-city master plan (Laituri, [11]). Schwabach, a small German city, was selected by the federal government for a pilot study to develop a model for ecological city development to be emulated elsewhere in Germany, while in Sweden, all local authorities were required implement Local Agenda 21 plans to encourage environmental innovation (Mega, [12]).

The current, third phase - and focus of this study - began to manifest itself in the mid 2000s through the concurrent globalisation (in terms of geographic spread and international profile) and mainstreaming (in terms of policy uptake and practical implementation) of the eco-city phenomenon. Thus eco-city initiatives are dotted in rapidly increasing numbers around the globe; and several high profile policy initiatives at national and international levels have begun to promote eco-city innovation, such as the Clinton Climate Initiative (a collaborative project between the Clinton Foundation and the C40 Cities Climate Leadership Group), the European Commission's Eco-City Project, and the World Economic Forum's SlimCity knowledge exchange initiative [13].

\section{Survey aims and methodology}

For the present study, an initial 'horizon-scanning' of recent eco-city initiatives was carried out, in order, firstly, to determine the scale and extent of the phenomenon and to capture the diversity of projects. This was done by identifying eco-city initiatives through the analysis of relevant academic literature, conference proceedings, policy documents, and websites of international networks and interest groups (including Eco-Cities; Ecocity Builders; Ecocity World Summit; Sustainable Cities [14]). The terms/descriptors used were 'eco-city' and 'eco-town'. The search results were triangulated through cross-referencing of information/sources. While this methodology may not capture all eco-city developments (especially non-English, or local ones without international outreach), it should nevertheless be sufficiently comprehensive and robust to identify all major initiatives reported 
internationally. As this survey focuses on the recent period, earlier initiatives which did not go beyond conceptual stage or were abandoned (such as the Halifax and Whyalla eco-city projects in Australia) were not included.

The second aim was to sketch a brief profile for each identified eco-city initiative, including information about the nature of development, key actors involved, and availability of data. The third aim was to try to identify key trends and patterns across the identified eco-cities, with a view to developing a suitable typology. As a result, the sampled eco-cities were grouped according to the following categories and variables: (i) type of eco-city development (new development; expansion of urban area; 'retro-fit' development); (ii) development phase (pilot/planning stage; under construction; implemented); and (iii) key implementation focus/mode (technological innovation; sustainability visions; urban expansion; civic empowerment).

\section{Findings}

Using the above methodology, 79 eco-city initiatives were identified (status autumn 2009). As Table 1 (below) shows, these are spread globally. A majority are located in Europe (34), with Scandinavian countries, the United Kingdom and Germany heading the table. The second largest concentration is found in Asia/Australasia (27), followed by North America (9), Africa (4), Latin America (3) and the Middle East (2). In at least three countries, there are governmental initiatives under way involving a series of eco-cities: in England, the new ecotown projects of North-West Bicester, Rackheath, St Austell, and WhitehillBordon; in India, the cities of Kottayam, Puri, Thanjavur, Tirupati, Ujjain, and Vrindavan; in Japan, the cities of Yokohama, Kitakyusyu, Minamata, Obhirio, Shimokawes and Toyama.

These findings demonstrate the extent to which eco-cities have in recent years become a global phenomenon, not limited, as might have been assumed, to developed countries in the Western hemisphere. Innovative eco-city initiatives are as likely to be found in China, Kenya, Japan, South Korea, and South Africa, as in Canada, Germany, Great Britain, Sweden, and the United States. Some of the most original eco-city projects are currently in planning or under construction in the Middle East and East Asia. The findings also show quite how far eco-cities have moved on since the 1970s-1990s: from a relatively loosely defined concept with only a few, mainly experimental pilots, to a multitude of concrete, practiceled initiatives.

It may prove elusive to try to define narrowly what exactly is, and is not, an eco-city, especially as there currently is no accepted standard definition in use and as the agenda is fast evolving (see discussion, below). This study shows just how diverse the eco-city phenomenon nowadays is. Both conceptually and in practice, eco-cities come in many shapes and forms.

Three analytical categories have been used, in an attempt to identify possible patterns or trends among the surveyed eco-city initiatives (see Table 2 below).

The first relates to the type of development, whereby a distinction is made between: (I) new development - that is, a city built from scratch; (II) expansion 

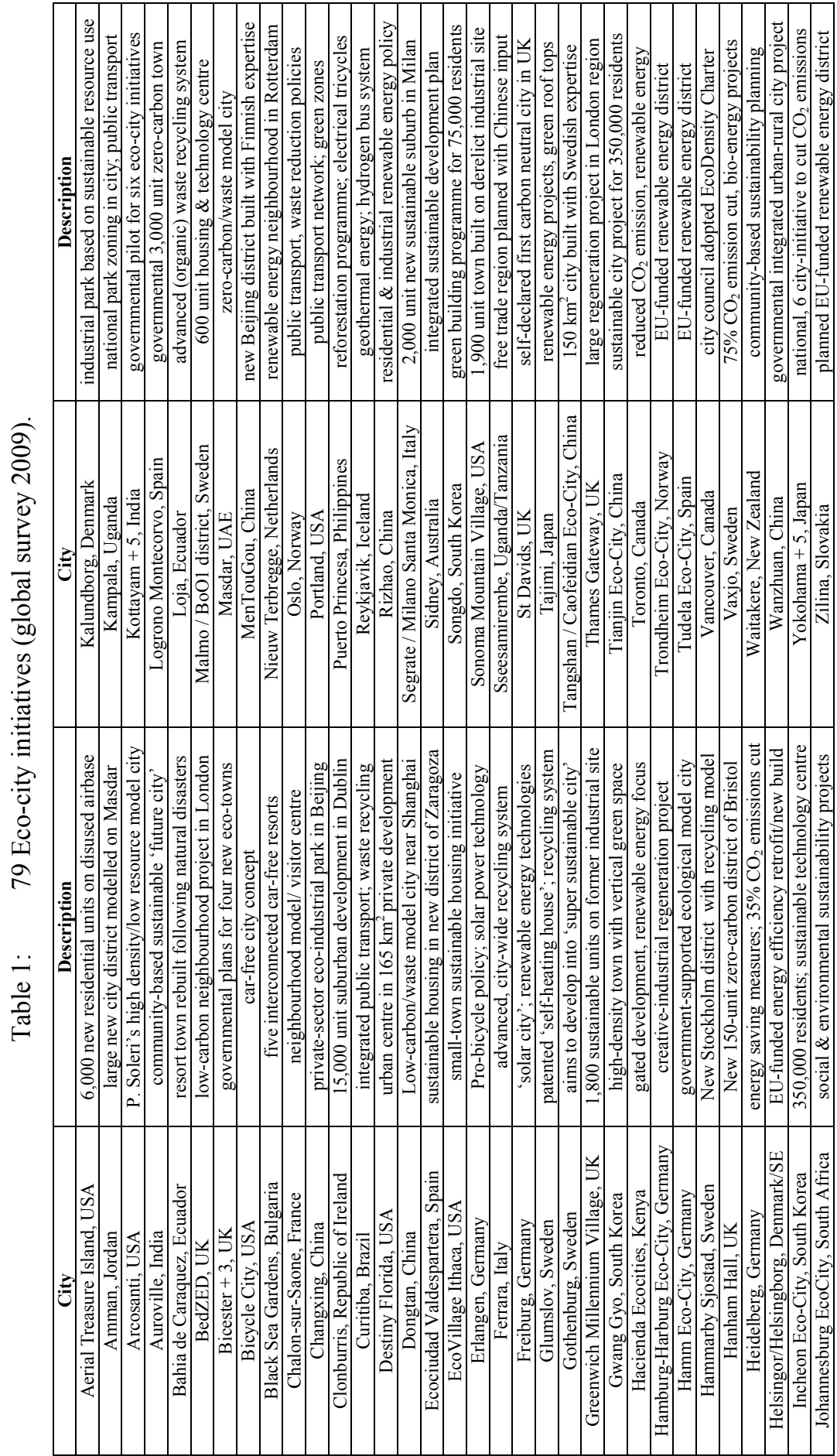

WIT Transactions on Ecology and the Environment, Vol 129, (C) 2010 WIT Press 


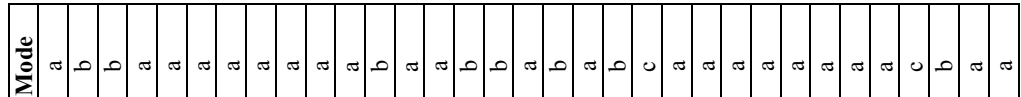

紊

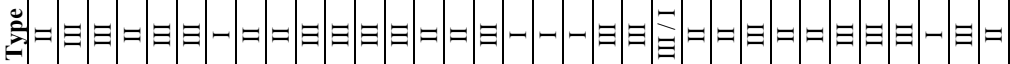

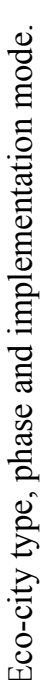

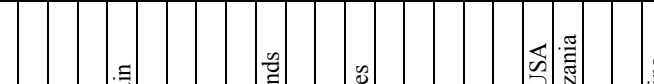

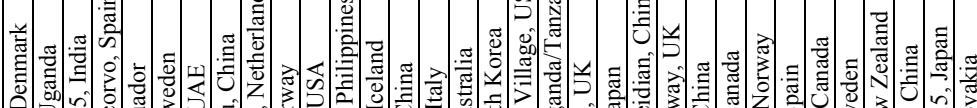

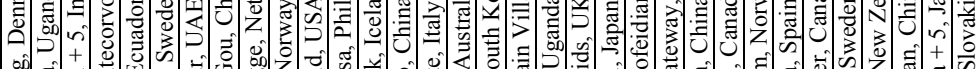

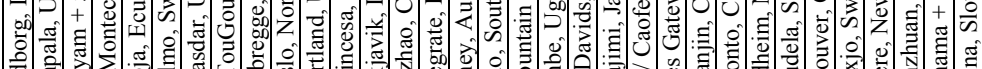

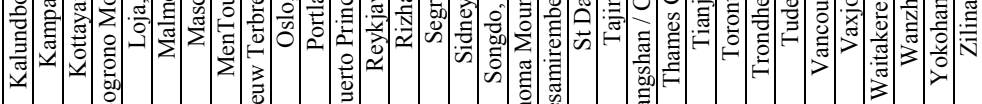
言

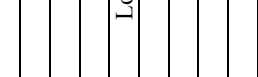

永

竞

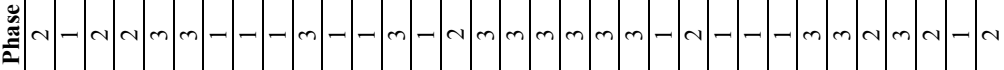

$\frac{\ddot{0}}{\frac{0}{0}}$

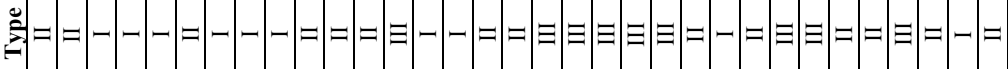

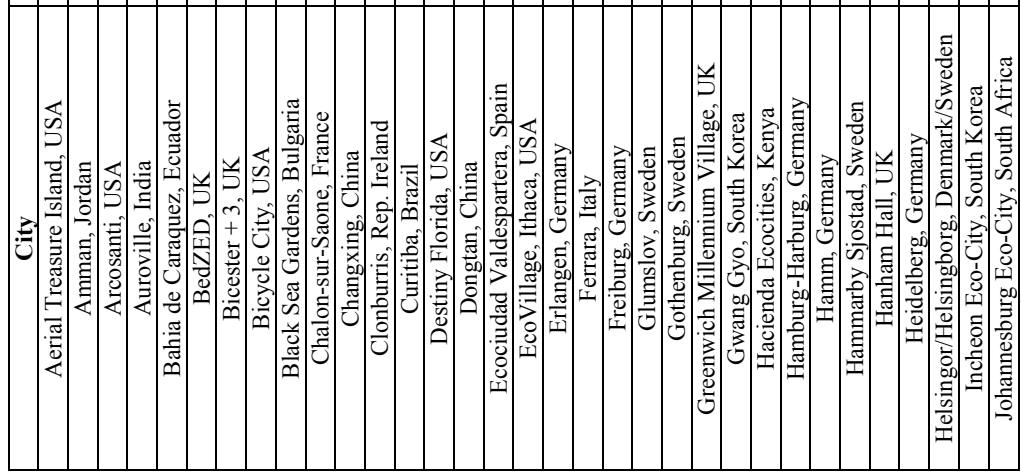

WIT Transactions on Ecology and the Environment, Vol 129, (C) 2010 WIT Press

www.witpress.com, ISSN 1743-3541 (on-line) 
of existing urban area - for example, a new district or neighbourhood; (III) 'retro-fit' development - that is, sustainability innovation/adaptation within existing urban infrastructure.

While in the media the most high-profile eco-city projects may be Type I, especially new cities built at large scale and through international consortia, such as Dongtan (China; with engineering firm Arup), Gwang Gyo (South Korea; with Dutch architects MVRDV) and Masdar (UEA; with Foster \& Partners and Massachusetts Institute of Technology, MIT), this analysis demonstrates that these represent just under $1 / 4$, with Type II making up over 1/4 and Type III just under $1 / 2$, of the total of surveyed initiatives. In other words, significant eco-city innovation takes place through the expansion of existing urban areas, such as Aerial Treasure Island, San Francisco (regeneration of former military airbase to provide 6000 new living units) and Greenwich Millennium Village, London (redevelopment of former gas works with 3000 residential units and ecology park), as well as through the 'retro-fitting' of existing housing stock, transport infrastructure, energy systems and waste management systems, such as Rizhao, China's acclaimed 'Garden City' (shift to renewable energy and 'greening' of inner city) and Trondheim, Norway (European Commission-sponsored model eco-city with focus on energy-efficient buildings, and waste-to-energy systems).

The second analytical category relates the development phase, thus distinguishing between whether an eco-city project is: (1) at planning stage; (2) under construction; or (3) implemented. It should be noted that while 'implemented' in this context means that the original eco-city plan has been achieved, it does not necessarily mean static: further innovation may well take place on a continuous basis. Approx. 1/4 of initiatives were at planning stage at the time of the survey, whereas just under $1 / 2$ were under construction, with more than $1 / 4$ having been implemented. This is a further indication of the rapid expansion of the eco-city phenomenon since the mid 2000s. It also reinforces the aforementioned point about important eco-city innovation taking place in existing cities either through expansion or 'retro-fitting', where developments are typically more advanced than in the case of new builds. Among the retro-fit examples, only two are presently at planning stage following their announcement in the second half of 2009 - the 'Eco-City Hamburg-Harburg' project to regenerate the old harbour as a sustainable creative-industrial environment, and the 'Gothenburg Super Sustainable City' master plan based on the city's recent 2050 sustainable futures project - while all others are either under construction or have been implemented. Freiburg (Germany) and Vaxjo (Sweden) have been known for years for their concerted efforts to render their cities more environmentally sustainable, with both cities variably being claimed as Europe's 'greenest city'.

The third category relates to the implementation focus - that is, the key modes by which eco-city plans are (to be) realised. This includes: (a) technological innovation; (b) integrated sustainability planning; (c) civic empowerment/involvement. This categorisation should not be understood too rigidly, as typically an eco-city development can be expected to combine two or more of these implementation modes (in some instances these may be in tension 
or competition with one another). It is, nevertheless, useful for pinpointing key features of eco-city development and the key actors involved, reflecting both international trends and local specificities.

Some $3 / 4$ of identified initiatives emphasise technological innovation as means of achieving eco-city development. Of these, a large majority focuses on energy technologies, including renewable energy. Freiburg, for example, has become known as Germany's 'solar city'; Sseesamirembe (Uganda) and Logrono Montecorvo (Spain) centre upon hybrid solar-wind power. A smaller proportion of 'technological innovation' cases focuses (in descending order) on waste management (waste-to-energy), transport infrastructure, and water management. The latter is a particularly pronounced in the case of the Indian governmental eco-city initiatives. Just under $1 / 4$ of cases take a more holistic sustainability approach (b) as a way of realising eco-city development, by emphasising the integration of technological, social and cultural aspects. Sidney (Australia) and St Davids (Wales) are examples of this category; the former with its Sustainable Sidney 2030 Vision master plan, implementation of which began in 2008; the latter emphasising the connection between technological innovation, behavioural change and education driven by local community involvement. The remaining few cases focus on civic empowerment and community involvement. Here, Tajimi (Japan), winner of the 2003 'Top Eco-City Contest of Japan', represents a 'top-down' approach in that the city authorities have take a lead in involving citizens and stakeholders in hearings with policy-makers in relation to the implementation of the city's environment plan. In contrast, Auroville (India) represents a 'bottom-up' approach in that developments are decided and implemented by the community.

The aforementioned strong technology focus can probably be explained by the mainstreaming of eco-cities in recent years. This may arguably have led to the dilution of the original ideas and concepts (with emphasis on social justice, civic empowerment and local democracy), which do not appear to feature largely in many current projects, and the prevalence of mainly technocratic approaches reflecting current climate change and urbanisation policy frameworks.

\section{Discussion}

The results of this survey reveal four broad features of the emerging eco-city phenomenon: firstly, following two earlier, more conceptual and experimental phases, it has undergone rapid and dynamic development since the mid 2000s characterised by a mushrooming of practical eco-city initiatives. The significant number of projects identified in this survey, and the pace of new initiatives being announced, are confirmation of this trend. Secondly, the phenomenon appears to be increasingly global, with significant initiatives on all continents and by growing international networks among interested parties engaged in knowledge exchange. Thirdly, it is characterised by a diversity of conceptual approaches, forms, scales, and implementation modes. Fourthly, it has become increasingly mainstream through embedding in policy-making, as evidenced by various governmental initiatives and programmes at local, national and international 
levels, such as the 'eco-budgeting' process adopted by Vaxjo city council; the climate change declaration by Freiburg city council; the English eco-town initiative; eco-city pilot schemes in India and Japan; the European Commission's eco-city project; and the international sustainable cities initiative by the C40 Cities Group and the Clinton Foundation.

Considering these features, the question arises as to how coherent a phenomenon the diverse eco-city initiatives are. The evidence suggests that it would be missing the point to define eco-cities narrowly as a socio-political phenomenon. For example, it would arguably be misleading to use the term exclusively for new developments (type I), given the very significant initiatives occurring within existing cities (type II/III). Likewise, it would be too limiting to confine the term to particular conceptual approaches and forms of implementation, given the rich diversity found. As the phenomenon expands, eco-cities can be expected to diversify further reflecting the various specific contexts of application.

However, it should still be useful - not least for the purposes of analysing the current phenomenon - to identify some key criteria as a way of demarcating ecocities. Here, the following three related criteria are suggested: (i) scale - an ecocity refers to an urban sustainability development of substantial scale in terms of the area, infrastructure and innovation concerned; (ii) sectors - development typically takes place across several sectors (housing, transport, energy, waste, water, land etc); (iii) policy - it is a development that is formulated as, embedded in, and supported by, policy processes. According to these criteria, small developments - such as single sustainable housing or waste plant projects (however important in themselves), or a publicity/branding exercise without substantive underpinning - are excluded from this definition on account of their lacking the scale and significance that require concerted, cross-sector application and policy commitment.

The purpose of trying to define eco-cities in such a way, then, serves not to impose a narrow concept or view on this evolving phenomenon, but rather to focus on its key dimensions, to map its contours based on an understanding of the overlapping and shifting boundaries between eco-city initiatives and 'normal' cities, and to facilitate critical inquiry into opportunities for and challenges to eco-city innovation.

Another question arising from this survey is what the significance of the emerging eco-city phenomenon is. How are we to understand the apparently fast growing interest in, and demands for, eco-cities? Detailed answers can be expected to be found in the analysis and comparison of individual cases - a subject for future research - pointing to specific causes and contexts. In more general terms, the combination of the following broad factors appears to be driving the phenomenon: on the one hand, against the background of the growing international recognition of global climate change threats and the related need for a shift towards a low-carbon economy, the 'greening' of cities has become a key (policy) demand given that they are currently estimated to account for approximately two thirds of global energy use and greenhouse gas emission (see, for example, Clinton Climate Change Initiative, [13]). On the other, rapid 
urbanisation - in 2008, for the first time over 50 percent of the global population lived in cities; this is expected to rise to 80 per cent by 2050 - creates pressure for enlarging existing, and building new, cities, particularly in developing countries, including in Africa (which has the highest rate of urbanisation at present), China and India.

A further factor is the aim to revitalise urban centres socio-economically by shifting away from old industries to new knowledge-based, green technology and creative industries, as illustrated by Hamburg-Harburg, Ecovillage Johannesburg, Kalundborg, Malmö, and MenTouGou. Some eco-city initiatives also explicitly emphasise their educational and research role, such as 'hands-on' demonstration sites/objects (for example, Vaxjo), visitor centres and museums (Chalon-sur-Saone; St Davids), and formal training and research programmes. Concerning the latter, Masdar, which aims to become the 'silicon valley for green energy', has plans for a sustainable engineering degree programme in collaboration with MIT; the Thames Gateway Institute for Sustainability [15] launched in early 2010 has a strong focus on 'retrofitting' environmental technology projects and plans to use the Thames Gateway, Europe's largest regeneration programme, as showcase; and the six Indian pilot eco-cities will be used to provide training for civil servants from other cities.

Finally, while, as argued above, in itself not sufficient, the eco-city label as tool for branding and marketing a city as innovative and sustainable seems a further factor driving the phenomenon. Thus, for example, since 2000 Japanese cities have competed for the top spot in the national eco-city contest; in the USA a list of top sustainable cities is published annually (with Portland, Oregon, and San Francisco currently occupying the top spots); and Vaxjo and Freiburg trade on the label as Europe's greenest cities. Destiny Florida [16], one of a few examples of commercial eco-city initiatives, advertises itself to potential residents as 'America's first eco-sustainable city'.

In trying to gauge the significance of eco-cities, both individually and collectively, it will be necessary to consider and assess outcomes - that is, to evaluate the degree to which the intended aims have been realised and what substantive results (for example, greenhouse gas emission cuts, increase in renewable energy, shift to public transport) have been achieved. Several cities can already point to specific achievements, such as the cut in $\mathrm{CO}_{2}$ emissions by over 30 per cent (compared to mid 1990s values) by Heidelberg and Vaxjo, respectively, and the introduction of hydrogen buses in Reykjavik (nicknamed 'hydrogen city'). However, in many instances (especially Phase 1 cases) this is premature owing to early stages of development. Equally important will be a critical assessment of underlying concepts and rationales, and how these correspond to the reality of eco-city implementation.

\section{Conclusion}

In setting out to systematically map, analyse and compare contemporary eco-city initiatives, this study has revealed a picture of a diverse, increasingly international and fast evolving phenomenon. Since the mid 2000s in particular, 
there has been a proliferation of new eco-city initiatives, which suggests that this phenomenon has gained considerable momentum and become embedded in mainstream policy-making.

It remains to be seen how far the prospects of eco-cities as a response to the triple challenge of global climate change, rapid urbanisation, and socio-economic regeneration will be realised in the process of translating visions and plans into action. This will partly depend on the processes of socio-technological innovation and political and socio-economic governance in play. Concerning the former, eco-cities can be understood as sites, or laboratories, of knowledge creation and transfer, through which new technologies and innovation processes are developed, tested and replicated. As this survey shows, various forms of innovation exist, some emphasising particular technologies and/or policy sectors, others using a more 'blended' approach of integrating different technologies, policy areas, concepts and visions. In addition, some eco-city projects have an explicit remit to foster social learning and education. Thus, future research should inquire into who and what drives these innovation processes, what are enabling and limiting factors, and what results are achieved.

Concerning the issue of governance, eco-cities are situated in, and have to adapt to, various contexts of social, economic and political governance. This is particularly so in the case of 'retro-fits', where innovation has to take place within, and relate to, often long-established governance structures and processes. Here, it will be important to learn from those initiatives - such as Freiburg, Portland, St Davids and Vaxjo - which appear to have effectively engaged with governance systems and processes. A 'clean slate' approach, using new developments, may initially seem to be less restricting in terms of having to fit into predetermined governance modes. Interestingly, however, there are several recent examples of new eco-city initiatives - including Dongtan, the English eco-towns, and Logorno Montecorvo - that have faced various, context-specific policy challenges and political controversies. Research, then, should inquire into how eco-cities are politically, economically and socially governed, what tensions and conflicts may arise between technological innovation, urban development and sustainable living, and how these may be resolved within a framework of democratic governance.

\section{Acknowledgements}

This research was supported with seed funding from the Nirman Foundation (Alexandria, USA). I am indebted to Robert Kargon, Arthur Molella and Daniel Tomozeiu for their contributions to this research. I would like thank John Barry, Anders Franzen, Peter Head, Gulliermo Reynes and Yvonne Rydin for their comments on an earlier version of this paper.

\section{References}

[1] Chrisafis A. Sarkozy unveils his legacy: Paris as a futuristic eco-metropolis. The Guardian, London, 29. April 2009, guardian.co.uk 
[2] Department of Communities and Local Government, www.communities. gov.uk/housing/housingsupply/ecotowns/; see in particular Eco-towns: Living a Greener Future. London, HMSO, April 2008.

[3] Masdar City, www.masdarcity.ae/en/home

[4] Wong, J.L. Eco-Infrastructure: letting nature do the work. www.greenleapforward.com/2009/02/27/eco-infrastructure-letting-naturedo-the-work/

[5] Barton, H. Sustainable Communities: the Potential for EcoNeighbourhoods, Earthscan Publishers: London, 2000.

[6] Downton, P.F. Ecopolis, Springer: Dordrecht, 2009.

[7] Kargon, R.H. \& Molella A.P. Invented Edens: Techno-Cities of the Twentieth Century, The MIT Press: Cambridge (Massachusetts), 2008.

[8] Register, R. Eco-city Berkeley: Building Cities for a Healthy Future, North Atlantic Books: Berkeley (California), 1987.

[9] Roseland, M. Dimensions of the eco-city. Cities, 14(4), pp. 197-202, 1997.

[10] Macedo, J. City profile Curitiba. Cities, 21(6), pp.537-549, 2004.

[11] Laituri, M. Cross-cultural dynamics in the eco-city: Waitakere City, New Zealand. Cities, 13(5), pp 329-337, 1996.

[12] Mega, V. Cities inventing the civilisation of sustainability: an odyssey in the urban archipelago of the European Union. Cities, 17(3), pp. 227-236, 2000.

[13] Clinton Climate Change, www.clintonfoundation.org, C40 Cities, www.c40cities.org, Ecocity Project, www.ecocity-project.eu, SlimCity, www.weforum.org

[14] Eco-Cities, www.eco-cities.net; Ecocity Builders, www.ecocitybuilders.org, Ecocity World Summit www.ecocityworldsummit.org, Sustainable Cities, www.sustainablecities.org.uk.

[15] Thames Gateway Institute for Sustainability, www.institutefor sustainability.co.uk

[16] Destiny Florida, www.destinyflorida.com 